\title{
ANNOUNCEMENTS
}

\section{The Transatlantic Walt Whitman Association}

In February 2007, fifteen scholars from Europe, the United States, and South America met in Paris, France, at Denis Diderot University (Paris 7) to organize The Transatlantic Walt Whitman Association. The group planned future conferences, seminars, and translation activities, and approved a charter for the organization, which will be headquartered at Tours University, academic home of Éric Athenot, who initiated the meeting. Anyone interested in more information about the Association or anyone wishing to join should contact Athenot by e-mail at <eric.athenot@wanadoo.fr>.

\section{The Charter of The Transatlantic Walt Whitman Association}

\section{Preamble:}

At the start of the twentieth century, a group of eminent Europeans sought "to found in Europe an organization ... [to] assemble all the European admirers of [Walt Whitman] and propagate his works" (Letter from Léon Bazalgette to Johannes Schlaf, 1907). A century later, The Transatlantic Walt Whitman Association believes that Whitman remains a crucial figure for remembering and re-imagining the literary, critical, and political roles that poetry plays in the world. The Association explores and fosters the artistic, democratic, and intercultural vision of Walt Whitman in the context of the need for improved European and transatlantic cooperation.

\section{The Transatlantic Walt Whitman Association seeks to:}

- promote the cultural and literary presence of Walt Whitman, re-reading and re-writing him for the current age;

- understand Whitman's significance in Europe's literary, political, and cultural heritage, as well as Europe's influence on Whitman's life and writings;

- promote the teaching ofWhitman's works, especially in their intercultural contexts;

- create a network of collaboration and exchange among teachers and students of Whitman, both within Europe and across the Atlantic;

- cooperate with, and support, the work of The Walt Whitman Archive and of the Walt Whitman Quarterly Review in making Whitman's writings, as well as writings about them, available to a broadening international audience;

- endorse and enable the work ofWhitman's translators;

- explore and foster the intersections between Whitman's writings and other forms of cultural, social, and political expression.

February, 2007

Paris, France 
Éric Athenot (Tours University), Marina Camboni (University of Macerata), Mario Corona (University of Bergamo), Jeanne Cortiel (Dortmund University), Sami El Hage (Paris IV), Betsy Erkkila (NorthwesternUniversity), Ed Folsom (The University of Iowa), Christine Gerhardt (Dortmund University), Jay Grossman (Northwestern University), Walter Gruenzweig (Dortmund University), Merel Leeman (Amsterdam), Kenneth M. Price (University of Nebraska), Marta Skwara (Szczecin University), Maria Clara Paro (University of São Paulo)

News of events sponsored by the Association will appear in $W W Q R$ and on the $W W Q R$ website (www.uiowa.edu/ wwqr/). 